\title{
Calvijns spreken over de caro vivifica in de avondmaalsleer christologisch verstaan
}

\author{
G.C. van de Kamp
}

\begin{abstract}
This essay argues that Calvin's Christology in its essence is defined by his Pneumatology. To that end it explores the concept of caro vivifica in Calvin's eucharistic doctrine. Because of his participation in the life of the Eternal word the caro Christi has become life-giving, a reality in which Christians share when they receive his body and blood in the Holy Supper. In both cases the Holy Spirit is the agent of mediation. The concept of caro vivifica clarifies Calvin's Christology because he understands the Word Incarnate to be a channel of life. Thus, in relationship to the Supper we may speak of a Spirit Christology as a complement to a Logos Christology.
\end{abstract}

Voor Calvijn is het avondmaal spiritueel en theologisch van grote betekenis. Dat blijkt reeds uit zijn pleidooi voor een wekelijkse viering. ${ }^{1}$ Deze wens is niet een eigenaardigheid, maar komt voort uit wat voor Calvijn het wezen van het geloofsleven is: 'het werkelijk deel hebben aan Christus en zijn weldaden.' In het accent op de gemeenschap met Christus klopt het hart van Calvijns theologie. Zij is ook de kern van Calvijns avondmaalsleer. Daarom horen avondmaalsleer en christologie bij elkaar. Hoek spreekt terecht over het avondmaal 'als een spiegel waarin we onze Here Jezus aanschouwen.'3

De avondmaalsleer kan gezien worden als spiegel van de christologie. De reformatoren ontwikkelden geen 'nieuwe' christologie. Hoe zij zich verhouden tot de klassieke christologie blijkt mede uit hun avondmaalsleer. Van Luther en Zwingli geldt dat in hun avondmaalsleer verwijzingen naar oude christologische controversen terugkeren. Luther vermoedde bij Zwingli de geest van Nestorius en zijn eigen avondmaalsopvatting wordt in verband gebracht met monofysitisme. ${ }^{4}$ Ook van Calvijn kan met recht gezegd worden: 'Het is

1 Jan Hoek, 'Een nooit vervulde hartenwens van Calvijn: elke zondag avondmaal', in: Rinse Reeling Brouwer e.a. (red.), Het calvinistisch ongemak. Calvijn als erflater en provocateur van het Nederlandse protestantisme, Kampen 2009, 171-183.

2 Jan Hoek, a.w., 176.

3 Jan Hoek, a.w., 179.

4 Zie bijvoorbeeld Otto Weber, Grundlagen der Dogmatik II, Neukirchen 1962, 150-153. 
geen toeval dat belangrijke elementen van wat Calvijn christologisch te zeggen heeft in zijn avondmaalsleer verweven zitten.' Het bijzondere van Calvijn is dat hij met name in de avondmaalsleer christologie en pneumatologie verbindt. ${ }^{6}$

In dit artikel wil ik vanuit de avondmaalsleer van Calvijn laten zien hoe zijn christologie tot in de kern bepaald is door de pneumatologie. Ik doe dit door een onderzoek naar het begrip caro vivifica. Het zal blijken dat hier nieuw licht valt op Calvijns christologie. Zeker ook bij Calvijn is er reden te spreken van een 'reformatorische geestchristologie.'7 De Geest van Christus schenkt ons in de viering van het avondmaal de gemeenschap met Christus in brood en wijn, zoals Hij in Christus God en mens, de goddelijke en de menselijke natuur, verenigt. De avondmaalsleer van Calvijn komt alleen breder aan de orde voor zover het van belang is voor dit artikel. ${ }^{8}$

\section{Herkomst van het begrip caro vivifica in de avondmaalsleer van Calvijn}

Het begrip caro vivifica speelt een prominente rol in Calvijns avondmaalsleer. ${ }^{9}$ Het is ontleend aan de uitleg van Johannes 6, maar over de vraag of dit hoofdstuk in verband kan worden gebracht met avondmaal of eucharistie bestaat in de geschiedenis van de uitleg geen eensgezindheid. ${ }^{10}$ Dat het begrip toch zo'n belangrijke plaats heeft gekregen in christologie en avondmaalsleer komt voor rekening van Cyrillus van Alexandrië. Hij spreekt over de menselijke natuur

5 Cornelis van der Kooi, 'Christologie', in: Herman J. Selderhuis (red.), Calvijn Handboek, Kampen 2008, 296.

6 Otto Weber, Grundlagen II, 153. Zie ook de studie van Christopher Ganski, Spirit and Flesh: On the Significance of the Reformed Doctrine of the Lord's Supper for Pneumatology, Dissertation Marquette University 2009. Beschikbaar via: http://epublications.marquette.edu/ dissertations_mu/173.

7 Ik ontleen deze benaming aan Otto Weber, Grundlagen II, 153.

8 Zie voor een korte samenvatting van Calvijns visie op het avondmaal W. Janse, 'Sacramenten', in: Calvijn Handboek, 387-398, vooral 394 vv. en uitvoeriger W. Janse, 'Calvin's Doctrine of the Lord's Supper', Perichoresis 10.2 (2012) 137-163 [online tijdschrift]. Beschikbaar via DOI: 10.2478/v.10297-012-0007-3. Daar is ook een literatuuropgave te vinden.

9 G.P. Hartvelt heeft het belang van dit begrip zo verwoord: 'Wij zijn ervan overtuigd, dat dit geheim van deze caro vivifica zich beweegt door de ganse avondmaalsleer van Calvijn', Verum Corpus. Een studie over een centraal hoofdstuk uit de avondmaalsleer van Calvijn, Delft 1960, 165.

10 Zie bijvoorbeeld de excurs 'Die Brotrede im Wandel der Auslegung, Rudolf Schnackenburg, Das Johannesevangelium II (HThKzNT IV.2), Freiburg-Basel-Wenen 1971, 96-102. 
van Christus als 'het levendmakende vlees van de Heer.'11

Zelf verwijst Calvijn in Institutie IV.17.9 bij zijn uitleg van Johannes 5:26 naar Cyrillus van Alexandrië. Hartvelt heeft een analyse gemaakt van de tekst waar Calvijn op doelt en plaatst Calvijns spreken over de caro vivifica in de bredere context van de avondmaalsleer van Cyrillus en diens verzet tegen Nestorius. ${ }^{12}$ Hartvelt is van mening 'dat Calvijn het gehele thema van de caro vivifica heeft overgenomen van Cyrillus' en concludeert dat Calvijn zich ook in de interpretatie van dit begrip bij hem heeft aangesloten. ${ }^{13}$ De centrale gedachte die Calvijn naar het oordeel van Hartvelt aan Cyrillus ontleent, is dat het vlees van Christus vanwege de unio personalis levenwekkend is. ${ }^{14}$ In dit artikel is geen ruimte om aandacht te geven aan Calvijns omgang met de teksten van de kerkvaders in het algemeen. ${ }^{15}$

Het spreken over het vlees van Christus als caro vivifica waaraan wij deelhebben in de viering van de maaltijd van de Heer is niet beperkt tot Calvijn of zelfs tot theologen uit het kamp van de Reformatie. In een aantekening van de uitgevers bij een brief van Bucer waarin hij spreekt over het deelhebben aan het vlees van Christus als levendmakend, schrijven zij: 'Die cyrillische Wendung caro vivifica bot Bucer die Möglichkeit, im innerprotestantischen Abendmahlsstreit eine gemeinsamen Position zu formulieren, da sie von Vertretern beider Seiten akzeptiert wurde, etwa von Philipp Melanchthon (...)

11 Bijvoorbeeld in de veroordeling van Nestorius op het concilie van Efeze (de tekst is van de hand van Cyrillus), maar ook in zijn commentaar op Johannes; het vlees heet levendmakend krachtens de eenheid met de levendmakende Logos. Zie voor de uitleg van de desbetreffende passages uit Joh. 6: Daniel A. Keating, The Appropriation of Divine Life in Cyril of Alexandria, Oxford 2004, 64-72 en voor de samenhang van christologie en avondmaalsleer Lawrence J. Welch, Christology and Eucharist in the Early Thought of Cyril of Alexandria, San Francisco 1994, speciaal 83, 84-87, 119 en 124.

12 Verum Corpus, 202-211.

13 Verum Corpus, 203 en 210.

14 Verum Corpus, 207. Zie voor de christologie van Cyrillus: Hans van Loon, The Dyophisite Christology of Cyril of Alexandria (Supplements to Vigiliae Christianae dl. 96) Leiden 2009; over Cyrillus en de eucharistie, bijv. 575-576.

15 Zie de dissertaties van J. Koopmans, Het oudkerkelijk dogma in de Reformatie. Bepaaldelijk bij Calvijn, Wageningen 1938 en R.J. Mooi, Het kerk- en dogmahistorisch element in de werken van Johannes Calvijn, Wageningen 1965. Voor een overzicht van de recente literatuur op dit gebied is de dissertatie van Sue Rozeboom zeer informatief; zie daar hoofdstuk 4: 'A survey of Past Responses to the Question at Hand and a Proposal for the Way Forward', Sue A. Rozeboom, The Provenance of John Calvin's Emphasis on the Role of the Holy Spirit regarding the Sacrament of the Lord's Supper, Indiana 2010, 154-174. Beschikbaar via: http://etd.nd.edu/ETD-db/theses/available/etd-11202010-211042/. 
und Johannes Oekolampad (...).'16 Ondanks de ruimere verspreiding van het begrip zal ik mij hier beperken tot Calvijn.

\section{Voorkomen en betekenis van caro vivifica in het werk van Calvijn ${ }^{17}$}

Het is terecht gewoonte geworden meer aandacht te geven aan de ontwikkelingen in Calvijns denken over het avondmaal. ${ }^{18} \mathrm{Om}$ deze reden geef ik een paar voorbeelden uit verschillende perioden. In de Confessio fidei de eucharistia uit 1537 lezen we:

Wij belijden dat het geestelijk leven dat Christus ons schenkt, niet louter gelegen is in het feit dat Hij ons door zijn Geest levend maakt, maar dat Hij ons ook door de kracht van zijn Geest deelgenoot maakt van zijn levendmakend vlees. Door daaraan deel te hebben worden wij gevoed tot eeuwig leven. ${ }^{19}$

In deze vroege tekst zijn de centrale momenten die telkens naar voren komen als Calvijn spreekt van de caro vivifica reeds aanwezig. Het deelhebben aan het levendmakende vlees van Christus is verbonden met het avondmaal en de Geest van Christus is de band die de deelname bewerkt. De tekst is tegelijk een voorbeeld van de realistische wijze waarop Calvijn over de avondmaalsgaven spreekt. Christus voedt ons werkelijk met de substantia van zijn lichaam en bloed. ${ }^{20}$

Een later voorbeeld van Calvijns spreken over de caro vivifica vinden we in zijn polemiek met de lutherse Heshusius uit 1561:

16 Reinhold Friedrich e.a. (red.), Martin Bucer Briefwechsel/Correspondance dl. IX (september 1532-juni 1533), Leiden 2014, 90, noot 35.

17 Voor de teksten van Calvijn raadpleegde ik: Ioannis Calvini Opera quae supersunt omnia, red. W. Baum, et al., Brunsvigae 1863-1900 (CO); Opera Selecta, red. P. Barth/W. Niesel, München 1926-1936 (OS) en Ioannis Calvini Opera omnia: denuo recognita et adnotatione critica instructa notisque illustrata, red. B.G. Armstrong et al., Series II, Opera Exegetica Veteris et Novi Testamenti, Genève 1992 e.v. (OE). Voor de Institutie gebruik ik de vertaling van C.A. de Niet, Johannes Calvijn, Institutie of Onderwijzing in de christelijke godsdienst [2 delen], Houten 2009 uitgegeven met een inleiding van W. van 't Spijker.

18 W. Janse, 'Calvin's Eucharistic Theology: Three Dogma-Historical Observations', in: Herman J. Selderhuis (red.), Calvinus sacrarum literarum interpres: Papers of the International Congres on Calvin Research (Reformed Historical Theology dl. 5) Göttingen 2008, 37-69; zie daar voor verdere literatuur.

19 Vitam spiritualem quam nobis Christus largitur, non in eo duntaxat sitam esse confitemur, quod spiritu suo nos vivificat, sed quod spiritus etiam sui virtute carnis suae vivificae nos facit participes, qua participatione in vitam aeternam pascamur (OS I, 435).

20 Ergo spiritum eius vinculum esse nostrae cum ipso participationis agnoscimus, sed ita ut nos ille carnis et sanguinis Domini substantia vere ad immortalitatem pascat, et eorum participatione vivificet (OS I, 435). 
Wanneer ik zeg dat het vlees en bloed van Christus ons in het avondmaal wezenlijk worden aangeboden en voorgehouden, geef ik tegelijk de wijze aan waarop het vlees van Christus voor ons levendmakend wordt: omdat Christus door de onbegrijpelijke kracht van zijn Geest uit de substantie van zijn vlees het leven dat Hem eigen is, in ons overgiet, opdat Hij zelf in ons leeft, en zijn leven ons deel wordt. ${ }^{21}$

Ook hier vinden we dezelfde momenten. Calvijn spreekt over hetgeen in het avondmaal wordt aangeboden als het vlees en bloed van Christus. Het leven gewordt ons uit de substantie van het vlees van Christus. ${ }^{22}$ Calvijn noemt kort na het hierboven gegeven citaat het vlees dat Christus bij de incarnatie aanneemt, materia spiritualis vitae. ${ }^{23}$ Ganski legt dit zo uit: 'According to Calvin the flesh of Christ is the "material" (materia) with which the Holy Spirit operates in our lives, such that one could describe the substance of the Christian existence as being nourished upon the flesh and blood of Christ.'24 Calvijn formuleert hier nog preciezer dan in het citaat uit de Confessio (zie boven) hoe de Geest het leven bemiddelt: Christus giet het leven uit zijn vlees in ons over door de kracht van zijn Geest. De tekst roept het beeld op van een kanaal. Hij gebruikt dit beeld zowel voor het vlees als voor de Geest. ${ }^{25}$

Als ik nu probeer de betekenis van de caro vivifica nader te bepalen, maak ik voorafgaand drie opmerkingen. (1) Het gaat bij Calvijn in de communie niet slechts om het deelhebben aan de schatten en gaven die Christus door zijn kruisdood verworven heeft (bona illa), maar om de gemeenschap met Jezus Christus zelf. ${ }^{26}$ (2) Ook al spreekt Calvijn over de caro vivifica in de con-

21 Quum substantialiter Christi carnem et sanguinem nobis offerri et exhiberi in coena dico, simul modum designo, quod Christi caro nobis sit vivifica: quoniam Christus incomprehensibili Spiritus sui virtute ex substantia carnis suae vitam in nos transfundat, quae illi propria est: ut ipse in nobis vivat, eiusque vita nobis sit communis (Dilucida explicatio sanae doctrinae de vera participatione carnis et sanguinis Christi in Sacra Coena ad discutiendas nebulas Heshusii, CO 9, 470).

22 Ook in het Petit Traicté de la Saincte Cene spreekt Calvijn over de gave van het avondmaal als: 'la propre substance de son corps en de son sang' (OS I, 510). Zie voor een analyse van Calvijns gebruik van materia en substantia: Frank Ewerszumrode, Mysterium Christi spiritualis praesentiae. Die Abendmahlslehre des Genfer Reformators Johannes Calvin aus römisch-katholischer Perspektive (Reformed Historical Theology dl. 19), Göttingen 2012, 83-86.

23 Distincte affirmo, quam a nobis sumpsit carnem, eam nobis esse vivificam, ut nobis sit materia spiritualis vitae $(\mathrm{CO} 9,470)$.

24 Christopher Ganski, Spirit and Flesh, 134.

25 Zie respectievelijk zijn commentaar op Johannes 6:51 (OE XI/1,214; zie voor de tekst: noot 39) en Institutie IV.17.12 (OS V, 356).

26 Institutie IV.17.11 Non enim ad nos bona illa pervenirent, nisi se prius nostrum Christus faceret (OS V, 354). 
text van het avondmaal, we zouden hem verkeerd verstaan als we de gave van het leven ( $v i t a$ ) beperken tot het avondmaal. Alle gaven die God ons meedeelt, worden ook buiten het avondmaal aan ons geschonken. ${ }^{27}$ Daartoe gebruikt God allereerst het Woord. (3) Maar dezelfde instrumentaliteit die Calvijn toekent aan het Woord, komt ook toe aan het sacrament van de maaltijd. Zowel het Woord als het sacrament is een instrument. ${ }^{28}$

Het leven als geschenk van God is de nieuw tot stand gebrachte relatie met Hem. Calvijn omschrijft de gave van het leven op verschillende manieren. In zijn uitleg van Efeziërs 4:18 noemt hij de vita Dei waarvan de heidenen vervreemd zijn wedergeboorte. Door de wedergeboorte leeft God in ons, genieten we zijn leven en leidt Hij ons door zijn Geest. ${ }^{29}$ De wedergeboorte is de noodzaak vernieuwd te worden door de genade van Christus.

Het leven is ook vergeving der zonden. ${ }^{30}$ De vergeving heeft alles te maken met het vlees van Christus waarin Hij verzoening tot stand gebracht heeft. In de uitleg van Johannes 6:51 zegt Calvijn over het levendmakende vlees van Christus:

In deze zin wordt het levendmakend genoemd, omdat het leven aan ons meedeelt, dat het van elders leent. Dit zal het minst duister zijn, als we bedenken wat toch de oorzaak is van het leven, immers gerechtigheid. Maar toch, ofschoon de gerechtigheid alleen van God uitgaat, wordt ze nergens anders zo volkomen duidelijk als in het vlees van Christus. Want daarin is de verlossing van de mensen vervuld, daarin is het offer om de zonden te verzoenen gebracht en de gehoorzaamheid aan God betoond die Hem met ons zou verzoenen. ${ }^{31}$

En bij Johannes 6:63 lezen we dat het leven ons door het vlees is meegedeeld, omdat God in het vlees met ons verzoend is. ${ }^{32}$

27 Hartvelt, Verum Corpus, 219.

28 Or, ce qui est dict de la parolle il appartient aussi bien au Sacrement de la Cene, par le moyen duquel le Seigneur nous meine à la communication de Iesus Christ (Petit Traicté, OS I, 505).

29 Sed per excellentiam regeneratio fidelium hic nominatur vita Dei, quoniam tunc proprie vivit Deus in nobis, et nos fruimur eius vita, quum Spiritu suo nos gubernat (OE XVI, 241).

30 In de uitleg van Johannes 3:36 wordt de vita gelijkgesteld met de gratuita remissio peccatorum $(\mathrm{OE} \mathrm{XI} / 1,114)$.

31 Atque hoc sensu dicitur vivifica, quod vitam, quam aliunde mutuatur, nobis communicat. Id minime obscurum erit, si reputemus, quaenam sit vitae causa, nempe iustitiam. Atqui quanvis a solo Deo iustitia fluat, non alibi tamen plena eius exhibitio nobis constabit quam in carne Christi. Nam in ea impleta fuit hominum redemptio, in ea oblatum sacrificium expiandis peccatis, obedientia Deo praestita quae ipsum nobis placaret (OE XI/1, 214-215).

32 Quia in ipsa placatus nobis est Deus (OE XI/1, 223). Vgl. Thomas J. Davis, The Clearest promises of God. The Development of Calvin's Eucharistic Teaching (AMS Studies in Religious Tradition I), New York 1995, 171. 
Het leven heeft dus te maken met wedergeboorte en vergeving van zonden. Het is gerechtigheid waaraan de gelovige deel krijgt. Nog dichter bij de betekenis van het leven dat de gelovige ontvangt, komen we door te letten op het aspect van onsterfelijkheid. Op het belang van de onsterfelijkheid als uitkomst van de deelname aan het levendmakende vlees van Christus is vooral gewezen door C. van der Kooi. Dit thema is voor Calvijn vanaf zijn vroege werk Psychopannuchia van grote betekenis geweest. Van der Kooi citeert de Institutie IV.17.8:

Ja, ook het vlees zelf, waarin Hij woont, geeft Hij ons als een levendmakend vlees, opdat wij door de deelname daaraan gevoed worden tot onsterfelijkheid. ${ }^{33}$

Ook al hangt het leven dat ontvangen wordt samen met de gerechtigheid die Christus in zijn vlees door zijn verlossend sterven getoond heeft, zoals blijkt uit het boven aangehaalde citaat uit Calvijns commentaar op Johannes 6, het accent ligt daar niet op. 'De tegenstelling van sterfelijkheid-onsterfelijkheid, verderfelijkheid-onverderfelijkheid is dominant en niet die van offer en voldoening. ${ }^{34}$

Maar meer dan deze gaven is het leven de gemeenschap met Christus zelf. Nadat Calvijn in zijn commentaar op 1 Korintiërs 11:24 de transsubstantiatie heeft verworpen, valt hij hen bij die zeggen dat wie Christus die voor ons gekruisigd en uit de doden opgewekt is, omhelzen, deelhebben aan zijn gaven (bona sua). Zelf wil hij echter verdergaan:

Maar ik zeg dat ze (= de gaven van Christus) verkregen worden, niet slechts wanneer we geloven dat Hij voor ons tot een offer gemaakt is, maar als Hij in ons woont, als Hij één met ons is, als wij leden van zijn vlees zijn, als wij (om zo te zeggen) ten slotte samen met Hem groeien tot één leven en één substantie. ${ }^{35}$

In de maaltijd van de Heer biedt Christus ons het lichaam waarin Hij heeft geleden en is opgestaan. Dat lichaam is voor ons voedsel dat heil brengt. Wanneer onze zielen gevoed worden met de substantie van zijn lichaam, worden

33 Quin et ipsam, in qua residet, carnem vivificam nobis reddit, ut eius participatione ad immortalitatem pascamur (C. van der Kooi, Als in een Spiegel. God kennen volgens Calvijn en Barth, Kampen 2002, citaat 196, vooral 194-198; ik volg hier de vertaling van de auteur. Ook Thomas Davis wijst op deze tekst uit de Institutie die reeds voorkomt in de editie van 1539, Clearest Promises, 115 en 139 noot 76.

34 Van der Kooi, Als in een spiegel, 196.

35 Obtineri autem dico, non tantum quum pro nobis factum fuisse victimam credimus: sed dum in nobis habitat, dum est unum nobiscum, dum eius sumus membra ex carne eius, dum in unam denique et vitam et substantiam (ut ita loquar) cum ipso coalescimus (CO 49, 487). 
we één met Hem en ontvangen we door de Geest de kracht uit het levendmakende vlees van Christus. ${ }^{36}$

De voorwaarden om zo te kunnen spreken over het leven dat we vanuit Christus' vlees ontvangen, liggen in christologie en pneumatologie. Daarover gaan de twee volgende paragrafen.

\section{Mogelijkheidsvoorwaarde van de caro vivifica}

Hoe kan het vlees van Christus levendmakend zijn? Anders gezegd, wat is de oorsprong van het leven dat in het vlees van Christus gelegen is? Het antwoord op die vraag zal de betekenis van het te ontvangen leven nog duidelijker maken. Leven geven is geen mogelijkheid van het vlees. Dat geldt ook van het vlees dat de Zoon heeft aangenomen.

Het (vlees) is van geen enkel nut, als het vanuit de eigen oorsprong en natuur wordt beschouwd, en ook schenkt het zaad van Abraham geen leven, omdat het op zichzelf beschouwd onderworpen is aan de dood. ${ }^{37}$

De reden dat het vlees van Christus wél leven schenkt, is gelegen in God die in de incarnatie tot de mens afdaalt.

In de commentaar op Johannes (1553) lezen we bij de uitleg van hoofdstuk 6:57 dat de levende Vader Christus gezonden heeft en dat Hij door de Vader leeft. God de Vader is zelf de bron van het leven. Maar deze bron is ver verwijderd van ons en verborgen. In Christus is de bron van het leven ons voor ogen gesteld. Daarom is Hij de tweede oorzaak van het leven. Uit Hem putten wij het leven. Door Hem komt tot ons wat anders in God verborgen zou blijven. Calvijn spreekt dus over het leven in drie trappen: allereerst het leven dat bij God is, dan het leven in de Christus als het vleesgeworden Woord en ten laatste het leven dat ons deel wordt. ${ }^{38}$

36 Concludo, realiter (ut vulgo loquuntur), hoc est, vere nobis in coena dari Christi corpus, ut sit animis nostris in cibum salutarem. Loquor vulgari more: sed intelligo, substantia corporis pasci animas nostras, ut vere unum efficiamur cum eo: vel, quod idem valet, vim ex Christi carne vivificam in nos per spiritum diffundi (CO 49, 487).

37 Calvijn, commentaar Johannes 6:63 (OE XI/1,223): Nihil prodest, si ex sua origine et natura aestimetur (neque enim vitam conferet Abrahae semen, quod per se morti est obnoxium).

38 Notandum est tres hic recenseri vitae gradus: primum locum obtinet vivens Pater, qui scaturigo est, sed remota et abscondita; sequitur Filius, quem habemus velut fontem nobis expositum et per quem ad nos vita diffunditur; tertia est vita, quam nos ab ipso haurimus. Nunc tenemus summam. Quia Deus Pater, penes quem residet vita, procul a nobis distat, Christus quasi medius statuitur, qui est secunda vitae causa, ut inde ad nos usque perveniat quod alioqui in Deo lateret (OE XI/1,220). 
Wat dit christologisch precies betekent heeft Calvijn duidelijk gemaakt bij zijn uitleg van Johannes 6:51. Daar spreekt hij over het eeuwige Woord van God als de bron van het leven. Het leven woont in de godheid van de Zoon, maar door de incarnatie wordt het vlees het kanaal waarlangs het leven naar de mensen vloeit. ${ }^{39}$ Nog anders gezegd: de verborgen kracht om het leven mee te delen komt toe aan het goddelijk wezen. Die kracht daalt neer op het vlees van Christus dat daardoor een wel wordt waaruit het leven geput kan worden. Calvijn spreekt over de neerdaling van de kracht als een tweede stap. Het leven dat intrinsiek is aan het eeuwige Woord daalt neer op het vlees. ${ }^{40}$

In het eerste geschrift waarin Calvijn zich verdedigt tegenover Westphal (1555) vinden we de mogelijkheidsvoorwaarde van de caro vivifica op gelijke wijze beschreven:

Want uit de verborgen bron van de godheid is het leven in het vlees van Christus uitgegoten om vandaaruit naar ons toe te stromen. (...)

Wij erkennen dat de heilige eenheid die wij met Christus hebben, voor het besef van het vlees onbegrijpelijk is. Dat Hij terwijl Hij ons met zich verenigt, ons niet alleen zijn leven indruppelt, maar ook één met ons wordt, zoals Hij zelf één is met de Vader, daarvan erkennen wij dat het een geheimenis is dat ons bevattingsvermogen te boven gaat. ${ }^{41}$

Ook in de Institutie vinden we deze redenering, al wordt hier niet zo onderscheiden in vitae gradus als in de commentaar op Johannes. Hij noemt het vlees van Christus 'een rijke en onuitputtelijke bron'. Het leven uit de Godheid welt op in het vlees dat op zijn beurt het leven op ons overgiet. ${ }^{42}$ Gerrish vat de gedachtengang van Calvijn als volgt samen:

39 Nam sicuti aeternus Dei Sermo fons vitae est, ita caro eius veluti canalis vitam, quae intrinseca (ut loquuntur) in divinitate residet, ad nos diffundit (OE XI/1, 214).

40 Quia vis illa arcana conferendae vitae, de qua loquutus est, ad divinam eius essentiam referri poterat, nunc descendit ad secundum gradum, ac vitam illam in sua carne positam esse docet, ut inde hauriatur (OE XI/1, 214).

41 Nam ex abscondito deitatis fonte in Christi carnem mirabiliter infusa est vita, ut inde ad nos flueret. (...) Sacram unitatem, quae nobis est cum Christo, sensui carnis incomprehensibilem fatemur esse. Quod nos sibi coniungens non modo vitam nobis suam instillat, sed unum quoque nobiscum efficitur, sicuti ipse unum est cum patre, sublimius captu nostro mysterium esse concedimus (CO 9,31).

42 Ita Christi caro instar fontis est divitis et inexhausti, quae vitam divinitate in seipsam scaturientem ad nos transfundit (Institutie IV.17.9; OS V, 350/1). 
The image is of a continuous stream of life gushing from its hidden source in the Father to the eternal Word, his Son, and then 'channelled' to the believer through the flesh of the Word incarnate. ${ }^{43}$

Zo kunnen we zeggen dat het vlees van Christus bron van leven is geworden door de hypostatische vereniging van de eeuwige Zoon van God (de Logos) met de menselijke natuur. ${ }^{44}$ De assumptio carnis is de mogelijkheidsvoorwaarde of de basis van het levendmakend vermogen van het vlees. Meer dan rechtvaardiging of zelfs onsterfelijkheid is het leven waaraan de gelovige deel krijgt, het leven van God. De levende en eeuwige God zelf is het leven dat Hij deelt met zijn mensenkinderen.

\section{Het vlees als drager of kanaal van leven}

De caro vivifica van Christus draagt leven waarvan de oorsprong op gelijke wijze gelegen is in God de Vader en het eeuwige Woord. In deze paragraaf zoek ik een antwoord op de vraag hoe het vlees van Christus drager kan zijn van dit goddelijk leven en op deze wijze kanaal van leven. Ik ga daartoe te rade bij de pneumatologie van Calvijn. In $\$ 2$ accentueerde ik bij de bespreking van het citaat uit het geschrift tegen Heshusius reeds het belang van de pneumatologie, omdat de gelovige door de Geest deelheeft aan het levendmakende vlees van Christus. De Geest verbindt de gelovige die op aarde is met het vlees van Christus dat na de hemelvaart in de hemel is. Zo ontvangt de gelovige de caro vivifica. In deze paragraaf gaat het om de plaats van de Geest in de christologie.

Er zijn twee manieren om in verband met de persoon van Jezus Christus over de Heilige Geest te spreken. Wanneer de Geest in het Nieuwe Testament de Geest van Christus wordt genoemd, betekent dat allereerst dat Christus, omdat Hij het eeuwige Woord van God is, door de Geest met de Vader verbonden is. Maar Hij is ook de Geest van Christus als Middelaar. ${ }^{45} \mathrm{Om}$ dat tweede aspect gaat het in deze paragraaf. Nog preciezer geformuleerd: het gaat om de vraag naar de plaats van de Heilige Geest in de verhouding van de naturen van Christus. Ik besef dat het risico aanwezig is verder te gaan dan Calvijn lief zou zijn. Immers 'men treft bij hem een diepe afkeer aan van

43 B.A. Gerrish, Grace and Gratitude. The Eucharistic Theology of John Calvin, Augsburg Fortress 1993 (2002), 132. Zie ook: Sue A. Rozeboom, The Provenance, 192-194.

44 Zie voor Calvijns omschrijving van de hypostatische vereniging Institutie II.14.5

45 Institutie III.1.2: Ac sciendum est, Spiritum Christi dici, non modo quatenus aeternus sermo Dei est eodem Spiritu cum Patre coniunctus, sed secundum Mediatoris quoque personam: quia nisi hac virtute praeditus, frustra ad nos venisset (OS IV, 2). 
christologische beschouwingen die proberen het geheim van de incarnatie denkend in de greep te krijgen.' ${ }^{46} \mathrm{Om}$ te zien hoe in de christologie de caro Christi (zijn menselijke natuur) zich verhoudt tot de Heilige Geest, kijk ik naar de wijze waarop Calvijn de Heilige Geest ter sprake brengt in de vleeswording zelf, het werk van Christus dat een aanvang neemt bij zijn doop en in zijn lijden en sterven. ${ }^{47}$

Vast staat dat Calvijn onverkort de waarachtige menselijke natuur van Christus leerde. In zijn commentaar op 2 Korintiërs 3:14 kan hij zeggen dat we het voornaamste fundament van ons geloof wegnemen, als we de natuur van Christus ongelijk maken aan de onze. ${ }^{48}$ Maar tegelijk is het vlees van Christus toch van 'bijzondere aard'. Dat heeft te maken met de zondeloosheid van Christus. Bij Lucas 1:35 tekent Calvijn aan dat de 'verborgen en hemelse oorzaak van zijn verwekking Hem heeft onttrokken aan de gewone orde' ${ }^{4}$ De Geest van God heeft Hem vanaf zijn oorsprong zuiver bewaard. ${ }^{50}$

In de Institutie spreekt Calvijn over het vlees van Christus als een tempel. Het Woord heeft zich uit de schoot der maagd een tempel gekozen om daarin te wonen. ${ }^{51}$ Hij wijst naar Johannes 2:19 waar Christus zijn lichaam een tempel noemt. ${ }^{52}$ Het beeld van de tempel keert terug in de commentaar op Hebreeën 8:2-4 waar Calvijn schrijft:

Zo is zijn vlees, dat uit het zaad van Abraham geboren is, omdat het een tempel van God was, levendmakend geworden; daarom is Christus' dood het leven geworden van de gehele wereld; hetgeen zeker de natuur te boven gaat. ${ }^{53}$

46 C. van der Kooi, 'Christologie’, Calvijn Handboek, 291.

47 Zie ook: S. van der Linde, De leer van den Heiligen Geest bij Calvijn. Bijdrage tot de kennis der Reformatorische theologie, Wageningen 1943, 84-97 en Werner Krusche, Das Wirken des Heiligen Geistes nach Calvin, (Forschungen zur Kirchen- und Dogmengeschichte dl. 7) Göttingen 1957, 126-140.

48 Quod si facimus humanam Christi naturam ita nostrae dissimilem, eversum est praecipuum fidei nostrae fundamentum (OE XV, 212).

49 Arcana et coelestis generationis ratio eum a vulgari hominum ordine exemit (CO 45, 31). Calvijn spreekt van zijn 'divina generatio' en noemt hem 'praeter ordinarium naturae modum conceptus ex spiritu sancto'.

50 Ab ipsa origine purum servavit Dei spiritus (CO 45,31$)$. 'Das conceptus de spiritu sancto ist erst richtig verstanden, wenn die generative Funktion des Heiligen Geistes zugleich als eine sanktifikatorische aufgefaßt wird, Krusche, Das Wirken, 132. Deze heiligende genade is de zogeheten gratia habitualis of gratia personalis.

51 Institutie II.14.1.

52 Institutie II.14.4.

53 Ita caro eius quae ex semine Abrahae orta erat, quum Dei templum esset, vivifica fuit, imo Christi mors totius mundi fuit vita; quod certe supra naturam est (OE XIX, 123-124). 
Het vlees van Christus is de woonstede van God of de Logos: daarin ligt de oorzaak van de levendmakende werking. Maar juist in deze context van het beeld van de tempel vinden we geen verwijzing naar de Heilige Geest. ${ }^{54}$

Bij de doop van Christus is er de zichtbare nederdaling van de Geest. Zijn verstaan van de doop van Christus laat zien dat Calvijn de Geest die aan Hem verleend wordt, uitlegt in de zin van de gratia capitis, de genade die Christus als het Hoofd van de verloste mensheid ontvangt ten bate van anderen. ${ }^{55}$ Maar anders dan in zijn spreken over de vleeswording van Christus zijn in verband met de doop van Christus teksten te vinden die enig licht werpen op de plaats van de Heilige Geest ter zake van de verhouding van de naturen in de persoon van Jezus. Enkele daarvan verdienen onze aandacht.

In zijn commentaar op Jesaja 42 spreekt Calvijn over de zalving van Jezus bij de doop. Door deze zalving met de Geest draagt Hij de naam Christus. Deze naam komt weliswaar toe aan de persoon, maar heeft in de eerste plaats betrekking op de menselijke natuur. ${ }^{56} \mathrm{Hij}$ is de met de Geest Gezalfde. Calvijn spreekt van de hemelse kracht die in de menselijke natuur van Christus woont. Daarom moeten wij, wanneer wij Hem horen spreken, niet zien op vlees en bloed, maar onze geesten hoger verheffen, opdat wij begrijpen dat al wat door Hem gedaan wordt goddelijk is. ${ }^{57}$ Christus had dit goddelijk geschenk van de Geest nodig om zijn werk als Middelaar tussen God en mensen te kunnen volbrengen. Zijn menselijkheid alleen volstond daartoe niet. In zijn menselijke natuur - in het vlees - ontvangt Jezus de kracht om het werk te volbrengen. ${ }^{58}$

Wanneer Calvijn in zijn commentaar op Jesaja 42 zegt dat 'hemelse kracht' in de menselijke natuur van Christus woont, betekent dit dus dat de Heilige Geest in Hem woont. De conclusie dat deze kracht een andere benaming is voor de Heilige Geest, ligt immers voor de hand. Ook andere teksten ondersteunen deze gelijkstelling. ${ }^{59}$

De Heilige Geest maakt niet alleen het werk van Jezus als Middelaar mogelijk, maar maakt ook dat zijn heerlijkheid die bij Hem als Zoon van God hoort,

54 Ook niet in zijn uitleg van 1 Korinthiërs 3:16-17 en 6:19 (CO 49, 357-358, 399).

55 Krusche, Das Wirken, 133-137.

56 Commentaar op Jesaja 42:1 Caeterum hoc nomen tribuitur personae, refertur tamen ad humanam naturam $(\mathrm{CO} 37,58)$.

57 Coelestis virtus in humana Christi natura habitat dum ipsum audimus loquentem, ne carnem aut sanguinem spectemus, sed altius erigamus mentes, ut quidquid ab eo agitur divinum esse intelligamus (CO 37, 59).

58 Oportuit autem Christum praeditum esse spiritu Dei, ut divino illo munere fungeretur, Deique et hominum mediator esset: quia humanitus tanta res peragi non poterat (CO 37, 59).

59 Voorbeelden bij Krusche, Das Wirken, 128, noot 7; Rozeboom, The Provenance, 180, noot 600. 
op aarde zichtbaar wordt, ook al hebben slechts weinigen deze heerlijkheid gezien. ${ }^{60}$ De heerlijkheid van het vleesgeworden Woord is dan ook geen externa pompa, maar splendor spiritualis, waarbij spiritualis staat tegenover terrenus.

Zoals de Zoon van God zich ontledigd heeft door het vlees aan te nemen, zo is ook in Hem de geestelijke kracht zichtbaar geworden die bewijst dat Hij God is. ${ }^{61}$

De Geest staat voor wat in Christus zijn godheid openbaart.

Met de naam van de Geest vat hij (de auteur van de brief) alles samen wat in Christus goddelijk was en de mens te boven ging. ${ }^{62}$

Maar deze virtus spiritus is pas na de opstanding in alle luister zichtbaar geworden. ${ }^{63}$ De kracht van de Heilige Geest is pas in zijn opstanding op zodanige wijze verschenen dat voor ieders oog zichtbaar werd dat Christus de Zoon van God is. ${ }^{64}$ Door de Geest is Christus levend gemaakt. ${ }^{65}$

Het vlees van Christus is door de Heilige Geest vanaf de incarnatie woonplaats geworden van goddelijk leven. De kracht en het leven van God wonen in zijn menselijke natuur door de Geest. Het leven Gods in het vlees van Christus is de Heilige Geest. Anders gezegd: het eeuwige Woord dat vlees heeft aangenomen doorwoont het vlees met dezelfde Geest die Hem met de Vader verbindt. In de maaltijd van de Heer verbindt de Heilige Geest ons met dit vlees. ${ }^{66}$

\section{5. 'Alleen de Geest maakt Hem één met ons' ${ }^{\text {'7 }}$}

De gelovige ontvangt het goddelijk leven door de Geest. Reeds in zijn commentaar op Romeinen zegt Calvijn dat de kracht om levend te maken rust in

60 Intelligit ergo Euangelista conspectam fuisse in Christo gloriam, quae Filio Dei congrueret certumque esset divinitatis testimonium (commentaar op Johannes 1:14, OE XI/1, 32).

61 Sicuti carnem induendo se exinanivit Filius Dei: ita et in ipso spiritualis apparuit virtus, quae Deum esse testatur (commentaar op 1 Timotheüs 3:16, CO 52, 290).

62 Spiritus nomine comprehendit quidquid in Christo divinum fuit ac supra hominem (CO $52,290)$.

63 Nec divina virtus spiritus ante resurrectionem lucide conspecta est (commentaar Mattheüs 27:57-61 p.p.; CO 45, 787).

64 Nam in Christi resurrectione talis apparuit Spiritus sancti potentia, quae Christum esse filium Dei palam faceret (commentaar op Johannes 6:61-62, OE XI/1, 222).

65 Christum spiritu vivificatum esse (commentaar op 1 Petrus 3:21, CO 55, 269).

66 Hier verschil ik van mening met Frank Ewerszumrode die het punt waar Calvijn de christologie met de pneumatologie verbindt, zoekt in het zogeheten extra calvinisticum, Mysterium Christi, 182-186 (185).

67 Institutie III.1.3 
de Geest van Christus. ${ }^{68}$ In Institutie III.1.3 lezen we:

Want door ons Zijn kracht in te blazen schenkt Hij ons het goddelijke leven in die zin dat wij ons niet meer uit onszelf bewegen, maar door Zijn werking en beweging geleid worden, zodat het goede dat er in ons is, de vrucht van Zijn genade is. ${ }^{69}$

Even verder vinden we na een verwijzing naar Efeziërs 5:30 de woorden die ik als opschrift meegaf aan deze paragraaf:

Maar alleen de Geest maakt Hem één met ons. ${ }^{70}$

De gemeenschap met Christus rust in het werk van de Geest. Zonder overdrijving kan S. van der Linde in zijn studie over de leer van de Heilige Geest bij Calvijn schrijven: 'De grootste weldaad die Christus ons bewijzen kan, is de opname in de gemeenschap met Hem, de unio mystica. De Heilige Geest bewerkt haar, is er het vinculum van. Door deze unio mystica worden wij vereend met Christus' dood en opstanding, zoodat Hij in ons gestalte aanneemt en niet langer werkeloos in ons terneer ligt.'71

Maar hoezeer de vereniging met Christus pneumatologisch geïnitieerd en volbracht wordt, er is sprake van een werkelijke vereniging met het lichaam van Christus. Daarop ziet in Institutie III.1.3 de verwijzing naar het huwelijk als beeld van de gemeenschap met Christus die ons tot leden van zijn lichaam maakt: caro de carne eius et ossa ex ossibus. ${ }^{72}$

In zijn commentaar op de brief aan de Efeziërs legt Calvijn Efeziërs 5:30 verder uit. De eenheid die er was tussen Adam en zijn vrouw is er ook tussen Christus en de gemeente:

Omdat Hij zich in zekere zin in ons overgiet. Want wij zijn niet beenderen van zijn beenderen en vlees van zijn vlees, omdat Hij zelf mens is mét ons, maar omdat Hij ons door de kracht van zijn Geest in zijn lichaam invoegt, opdat wij uit Hem leven putten. ${ }^{73}$

68 Commentaar op Romeinen 8:10: Respondet ergo, vim vivificandi in Spiritu Christi inesse, quae ad mortalitatem nostram absorbendam valeat (OE XIII, 161).

69 Quia virtutis suae afflatu divinam nobis vitam sic inspirat ut non iam agamur ipsi a nobis, sed eius actione ac motu regamur, ut siqua sunt in nobis bona, fructus sint gratiae ipsius (OS IV, 4).

70 Solo autem Spiritu unit se nobiscum (OS IV, 5).

71 S. van der Linde, De leer van den Heiligen Geest, 95.

72 OS IV, 5.

73 Eadem ergo unionis ratio inter nos et Christum, quod se quodammodo in nos transfundit. Neque enim ossa sumus ex ossibus eius, et caro ex carne, quia ipse nobiscum est homo, sed quia Spiritus sui virtute nos in corpus suum inserit, ut vitam ex eo hauriamus (commentaar op Efeziërs 5:31, OE XVI, 273). 
Het zijn bij uitstek de sacramenten van doop en avondmaal die deze werkelijkheid verbeelden. Voor de doop verwijs ik naar Calvijns uitleg van Romeinen 6:5. ${ }^{74}$ Hij interpreteert deze tekst als een enting ${ }^{75}$ door Gods hand volbracht. Wanneer een tak op een boom geënt wordt, ontvangt hij voeding van de boom. Maar de vrucht aan de geënte tak behoudt haar natuurlijke eigenschappen. Wanneer echter een gedoopte in Christus geënt wordt, onttrekt deze niet alleen levenskracht en levenssap aan Christus, er is sprake van een verhuizing: we verhuizen uit onze natuur naar de zijne. ${ }^{76}$ Elders schrijft hij dat wie door de doop in Christus zijn ingeplant tegenover God de naam en de persoon van Christus dragen. ${ }^{77}$

Wanneer Calvijn in zijn commentaar op Efeziërs spreekt over het huwelijk dat verwijst naar de innige band van Christus en zijn gemeente komt het avondmaal ter sprake. Zoals Eva geformeerd is uit de substantia van Adam en zo als het ware deel van hem is, zo zijn wij leden van het lichaam van Christus en delen we in zijn substantia. Door deze gemeenschap groeien wij tot één lichaam.

Paulus beschrijft hier dan ook die eenheid van ons met Christus, waarvan ons in het heilig avondmaal een teken en onderpand wordt gegeven. ${ }^{78}$

Calvijn bestrijdt in het vervolg wie beweren dat het in Efeziërs 5 niet om het avondmaal gaat, maar over het huwelijk. Dat zijn namelijk degenen die het avondmaal alleen zien als commemoratio en niet als communicatio. Juist omdat Paulus zegt dat wij uit Christus zijn (ex membris et ossibus Christi), verwonderen we ons er niet over dat Hij ons zijn lichaam aanbiedt in het avondmaal als voedsel voor het eeuwige leven. ${ }^{79}$

Het sterke accent op de vereniging met het waarachtige lichaam van Chris-

74 In de commentaar van Calvijn is de tekst: Nam si insititii facti sumus similitudini mortis eius, nimirum et resurrectionis participes erimus (OE XIII, 120).

75 In het Latijn: insitio. Dit wijst zeker op de doop. Calvijn omschrijft de doop immers als in Christus ingeplant worden. Het doel van de doop is: ut Christo insiti inter filios Dei censeamur (Institutie IV.15.1; OS 5, 285).

76 In hac (scl. insitione) autem non modo vigorem ac succum vitae a Christo trahimus, sed in eius naturam ex nostra demigramus, commentaar op Romeinen 6:5, OE XIII, 121 (verwijzing bij S. van der Linde, De leer van den Heiligen Geest, 95, noot 4).

77 Sed intelligit Christo sic esse insitos, ut coram Deo nomen ac personam Christi gerant ac in ipso magis quam in seipsis censeantur (commentaar op Galaten 3:27; OE XVI, 86; bij W.F. Dankbaar, De sacramentsleer bij Calvijn, Amsterdam 1941, 100).

78 Denique eam nostri cum Christo unionem hic Paulus describit, cuius in sacra Coena symbolum et pignus nobis datur (commentaar op Efeziërs, OE XVI, 272).

79 Miramur ergo si corpus suum in coena fruendum nobis exhibet, ut sit nobis vitae aeternae alimentum? (OE XVI, 272). 
tus als bron van leven enerzijds en het accent op het werk van de Geest anderzijds waardoor de gelovige deelt in dit leven, ${ }^{80}$ zijn de brandpunten van de avondmaalsleer van Calvijn. Samen wijzen ze op een christologie die kan worden verstaan als een vorm van geestchristologie. Omdat Calvijn de klassieke christologie en triniteitsleer handhaaft, moet geestchristologie hier verstaan worden als pneumatologische christologie. ${ }^{81}$ Het leven dat inherent is aan het vlees van Christus, is gave van de Geest aan de menselijke natuur van Christus. De Heilige Geest heiligt de menselijke natuur van Christus (gratia habitualis). Maar de gave van de Geest mag niet los gezien worden van de vereniging der naturen die met de vleeswording gegeven is. Ze is effect van de gratia unionis. De Logos die de bron van het leven is dat Hij met de Vader deelt, is door de Geest het leven van het vlees waarom het vlees caro vivifica heet. De Catechismus van Heidelberg kan daarom belijden dat deelname aan het avondmaal betekent dat wij door de Heilige Geest die én in Christus én in ons woont, verenigd worden met zijn heilig lichaam (vraag en antwoord 76).

G.C. van de Kamp is emeritus predikant van de Protestantse Kerk in Nederland.

80 Calvijn schrijft dat we leven putten uit Christus (zie boven en noot 73), maar evenzeer kan hij schrijven dat we putten uit de Geest van Christus (in een brief aan Bullinger uit 1547, zie bij F. Ewerszumrode, Mysterium Christi, 152 (noot 151).

81 Ralph del Colle spreekt op dezelfde wijze van geestchristologie, Christ and the Spirit. SpiritChristology in Trinitarian Perspective, New York-Oxford 1994, 3-7 (4). Vgl. ook mijn 'De pneumatologische christologie van David Coffey', Nederlands Theologisch Tijdschrift 66 (2012) 120-134. 